Research Article

\title{
Effects of Strongbacks and Strappings on Vibrations of Timber Truss Joist Floors
}

\author{
Shuo Xue $\mathbb{D}^{1},{ }^{1}$ Zhanyi Zhang $\mathbb{D}^{2},{ }^{2}$ Zhanyi Zhang $\mathbb{D}^{3},{ }^{3}$ Haibin Zhou $\mathbb{D}^{2,4}$ and Yinlan Shen ${ }^{5}{ }^{5}$ \\ ${ }^{1}$ China State Railway Group Co., Ltd., Beijing 100844, China \\ ${ }^{2}$ Research Institute of Wood Industry, Chinese Academy of Forestry, Beijing 100091, China \\ ${ }^{3}$ China Orient Institute of Noise and Vibration, Beijing 100085, China \\ ${ }^{4}$ National Engineering Research Center of Wood Industry, Beijing 102300, China \\ ${ }^{5}$ Beijing University of Technology, Beijing 100124, China \\ Correspondence should be addressed to Haibin Zhou; dvchow@126.com
}

Received 28 December 2020; Revised 27 May 2021; Accepted 28 June 2021; Published 7 July 2021

Academic Editor: Nerio Tullini

Copyright (c) 2021 Shuo Xue et al. This is an open access article distributed under the Creative Commons Attribution License, which permits unrestricted use, distribution, and reproduction in any medium, provided the original work is properly cited.

\begin{abstract}
It is well known that the vertical vibrations of lightweight timber floors would cause discomfort to the occupants. As a new kind of flooring system, the metal-plate-connected timber truss joist floors were developed due to their larger spans and easier crossing of pipes and cables after sawn timber and I-joist floors. In this paper, the vibration modes and transfer functions of sixteen metalplate-connected timber truss joist floors over a nominal span of $6 \mathrm{~m}$ were determined experimentally to measure the changes in vibration frequencies and transmissions obtained after the installation of strongbacks and strappings. The results showed that the fundamental natural frequencies of the metal-plate-connected timber truss joist floors at a $400 \mathrm{~mm}$ joist spacing were about $15 \mathrm{~Hz}$, while the frequencies of the floors at a $600 \mathrm{~mm}$ joist spacing were about $12.5 \mathrm{~Hz}$. The bracing elements of the strongbacks and strappings mainly enhanced the system stiffness in the across-joist direction of the flooring system, but they did not govern the fundamental natural frequencies of the floors and just changed the spacing of adjacent natural frequencies. The bracing elements as secondary elements of the floors also altered the vibration transmission paths in the across-joist direction. The frequencies where the stronger vibration transfers happened in the direction perpendicular to floor joists were generally above $15 \mathrm{~Hz}$. Proper installation measurements of bracing elements in practical control need to be taken to alleviate the vibration response intensity at the targeted locations and frequencies.
\end{abstract}

\section{Introduction}

Timber floors are by far the most common structural systems used in timber-framed buildings around the world [1]. Timber flooring systems are typically constructed with timber floor joists and wood-based sheathing. Compared with concrete floors, timber floors with lightweight construction have a low mass-to-stiffness ratio [2]. Problems regarding floor vibrations of timber floors are easily produced by the daily activities of occupants, such as walking, running, and jumping [3]. Because in a building the flooring system is only a structural system where occupants are in constant physical contact, the vertical vibration problem is a source of annoyance to occupants $[4,5]$. Even though floor vibrations do not cause failure of a structure, it generally makes many people feel uneasy and will create fear of structural collapse, although such fear is unnecessary because of the small motions that are actually presented. Numerous efforts have been made to identify factors affecting human response to vibrations of joist-type floors [5-10]. It was concluded that frequency components, vibration amplitude, and damping of vibration were the most important factors affecting human response to vibrations [1]. The fundamental research for understanding the factors affecting human response to floor vibrations has paved the way for the development of design approaches to prevent annoying vibrations. With field investigations on the construction details and subjective evaluations on laboratory- 
constructed floors and floors in the occupied buildings, the correlations between human perceptions and vibration performances were statistically analyzed and some design criteria limiting the static deflection, vibration responses, or combination of some parameters were proposed $[3,5,11-14]$. These design approaches commonly targeted timber floors for different purposes to prevent objectionable vibrations.

Whether these design criteria are rational to vibration serviceability of timber floors or not, it is primarily important for any timber floor design engineer to systematically clarify the performances of timber flooring structures on the vibration responses and build the corresponding relationships. The fundamental natural frequency of a timber floor is governed predominantly by the system stiffness in the joist direction $[3,6,14,15]$. The spacing of two adjacent natural frequencies is controlled by the ratio of the perpendicular floor stiffness to the longitudinal floor stiffness [1]. Many construction details, such as floor decking thickness and material, attachment of floor decking to joists, lateral elements, and ceiling, contribute to the perpendicular floor stiffness. Natural frequencies, damping ratios, and mode shapes of a prefabricated floor element were influenced by floor fixing boundary conditions and construction stages [16]. The construction details, such as the way that components are attached and the boundary conditions at supports, can contribute to the Coulomb damping. The addition of dead loads, for example, installation of nonstructural elements, can also have considerable effects on the effective damping $[7,9,16]$. The presence of partitions on floors was found to provide exceedingly high damping [17].

With the availability of engineered timber joists and trusses which evolved from traditional lumber joists, timber floor systems become longer span and continuous multispan systems. For architectural designers and structural engineers, the advent of stronger materials, lighter and more rigid cladding, smaller damping, longer spans, and more accurate strength calculations taking into account the interaction of components means that excessive vibrations now have a greater influence on structural design than before. Three types of parallel chord trusses, including gluejointed timber trusses, open metal web trusses, and metalplate-connected timber trusses, are generally used as timber floor joists in low-rise residential houses, benefited from large span, high strength, easy prefabrication, and convenience for crossing pipelines. Due to different structural compositions among joist products, the design methods based on other timber floors built from different joist products may have a discrepancy in vibration acceptability [18]. Timber truss joist floors are no exception. New construction practices have had a profound impact on the vibration characteristics of some timber floors [19]. Few literature works on the vibration performances of timber truss joist floors were reported. In terms of the glue-jointed timber truss joist floors, the second and third natural frequencies of the floors were significantly changed by installing strongbacks and strappings, indicating that the bracing elements increased the floor stiffness perpendicular to the joist direction [20]. With respect to open metal-web joists floors, the joist spacing and ceiling had no obvious influences on the fundamental natural frequency but had obvious influences on the natural frequencies of higher modes [21]. The dynamic responses of timber floors constructed with metal-web truss joists were also investigated by conducting field tests [9].

Moreover, the perception of timber floor vibrations was usually subjectively evaluated from the walking person himself while ignoring the response of surrounding people. Vibration transfer in the flooring system should be considered especially for complex two-way timber truss joist floors with bracing elements in practical applications. It can determine the feasibility of some mitigation measures when the vibration responses are expected to be lessened at some locations in occupied truss joist floors with unacceptable vibrations or the design will be done to ensure the vibration responses at some interesting locations or paths under acceptable level for new timber truss joist floors. The acceleration responses from vibrations are not only related to the excitation intensity and the distance from the excitation point but also related to the floor structure. Although every excitation was from the same location, the acceleration at each response location is easily affected by the variation of the excitation intensity from these impacts [22]. The vibration transfer function of the floor is not affected by the excitation intensity, which can denote the transfer capacity to the vibration energy and transmission paths in the floor system [23]. Literature about the experimental impact assessments of structural changes on local and global vibration performances based on the vibration transfer function was limited for timber truss joist floors. In this paper, metalplate-connected timber truss joist floors were constructed at the National Engineering Research Center of the Wood Industry in Beijing, China. The improvements in the vibration performances from the construction details including the spacings of joists and strappings and the location and number of strongbacks were systematically assessed in order to find floor construction methods known to reduce the amplitudes of dynamic motions and the derived characteristics like acceleration and avoid the construction details that cause direct vibration transmissions.

\section{Construction of the Test Floors}

All the test floors were originally transformed from two base test floors with different joist spacings. The transformations were achieved from the installation of bracing elements like strongbacks or strappings. These two base test floors were designed according to the ratio of the maximum floor deflection to the floor span to $1 / 360$ under a uniform load of $1.9 \mathrm{kPa}$. The design span of the base test floors was $6 \mathrm{~m}$. The joist spacing and width of one base test floor (T1) were $400 \mathrm{~mm}$ and $5.6 \mathrm{~m}$, respectively, while the joist spacing and width of the other floor (T3) were $600 \mathrm{~mm}$ and $8.4 \mathrm{~m}$. The base floor joists were the metal-plate-connected timber trusses with parallel chords. Each test floor was constructed from fifteen trusses which were evenly distributed. The metal plates for connecting the timber trusses were manufactured at a timber construction company according to the standard 
JGJ/T 265-2012 [24], and the truss sketch is shown in Figure 1. The length of the trusses for all test floors was $6 \mathrm{~m}$ and the height of the trusses was $438 \mathrm{~mm}$. The flanges and webs of the truss were composed of $38 \mathrm{~mm} \times 89 \mathrm{~mm}$ sprucepine-fir (SPF) lumbers with J visual grade. According to the truss design, the precut flanges and webs at each node were connected with the galvanized metal connecting plates with a nominal thickness of $1 \mathrm{~mm}$, a teeth length of $10.45 \mathrm{~mm}$, a teeth width of $3.45 \mathrm{~mm}$, and a teeth density of 106-108 No/ $\mathrm{dm}^{2}$. The distance between adjacent nodes in the parallel direction was $500 \mathrm{~mm}$. To check whether trusses met the design requirement, three timber trusses were randomly selected for the third-point loading test. The midspan deflections under a vertical point load of $2.51 \mathrm{kN}$, equivalent to a uniformly distributed load of $1.9 \mathrm{kPa}$ on floors, were measures as $3.5 \mathrm{~mm}, 4.4 \mathrm{~mm}$, and $3.9 \mathrm{~mm}$, respectively.

The construction process of the base test floors is shown in Figure 2. To easily measure the floor deflections and install the bracing elements at the bottom of the test floors, these base test floors were constructed on the wall framing with a height of $1.85 \mathrm{~m}$. One door opening in one of four walls was prefabricated as the access to the experimenters. Each base test floor was composed of 15 truss joists. Each end of every truss joist was connected to the top plate of the exterior wall with $90 \mathrm{~mm}$ long lag screws. The bottom flange of the truss trimmer joist was fixed on the top plate of the wall with $70 \mathrm{~mm}$ long lag screws at $600 \mathrm{~mm} \mathrm{c} / \mathrm{c}$. The rim joist was the laminated veneer lumber (LVL) with the strength grade of $8 \mathrm{E}-33 \mathrm{f}$. The thickness of LVL was $38 \mathrm{~mm}$ and the height was $438 \mathrm{~mm}$. The LVL header joist was connected to the end straight web of each floor joist with one $70 \mathrm{~mm}$ long screw on top and one on the bottom. Moreover, the LVL rim board was fixed to the top plate of the supported wall with $70 \mathrm{~mm}$ long screws at $600 \mathrm{~mm} \mathrm{c/c}$. After the installation of truss joists, the OSB floor decking was sheathed on the floor joists with $30 \mathrm{~mm}$ long screws at $150 \mathrm{~mm} \mathrm{c/c}$ around the perimeter and at $300 \mathrm{~mm} \mathrm{c/c}$ in the field. The physical and mechanical properties of the OSB floor sheathing met the requirements in the standard LY/T 2389-2014, as shown in Table 1. The thicknesses of the OSB boards were $15 \mathrm{~mm}$ for the joist spacing of $400 \mathrm{~mm}$ and $18 \mathrm{~mm}$ for the joist spacing of $600 \mathrm{~mm}$. The layout of the OSB decking was perpendicular to the joist direction.

The base test floor with the joist spacing of $400 \mathrm{~mm}$ was called Floor T1, while another one with the joist spacing of $600 \mathrm{~mm}$ was named Floor T3. Before the installation of any bracing elements, two base test floors were named T1-1 and T3-1, respectively. Other test floors were evolved from these two base test floors T1-1 and T3-1, as listed in Table 2. Floors T1-2 and T3-2 were installed on a strongback at the midspan of Floors T1-1 and T3-1. Floors T1-3 and T3-3 had two strongbacks at the midspan of Floors T1-1 and T3-1. Floors T1-4 and T3-4 had one strongback at the midspan and one at each quarter span of Floors T1-1 and T3-1. Finally, Floors T1-5 and T3-5 had two strongbacks at the midspan and one at each quarter span of Floors T1-1 and T3-1. The changes were the installations of the bracing elements of strongbacks and strappings, which can be seen in Figure 3. The strongbacks were the SPF lumbers with visual grade J and the section dimensions of $38 \mathrm{~mm} \times 235 \mathrm{~mm}$. These strongbacks were laid perpendicularly to the joist direction and fixed with screws to the straight web members of fifteen timber truss joists. The strappings were also the SPF lumbers with visual grade $J$ and the section sizes of $19 \mathrm{~mm} \times 89 \mathrm{~mm}$. They were flatwise nailed to the bottom chords of these truss joists in the perpendicular direction to the joist direction. The spacings of the strappings were $300 \mathrm{~mm}, 400 \mathrm{~mm}$, and $600 \mathrm{~mm}$, respectively, for the two base test floors with different joist spacings.

\section{Test Methods}

3.1. Modal Testing. The measurement grid on the test floors consisting of seven equally spaced rows along span direction and joist lines is shown in Figure 4, and a total of 105 excitation locations were obtained. The five vibration response measurement locations were selected for attaining vibration response signals according to the asymmetric distribution and also by avoiding vibration nodal points, as seen in Figure 4. Five acceleration transducers (accelerometers) for vibration response measurement locations were mounted on the surface of the test floors. An exciting hammer with a rubber head was used to excite 105 excitation locations successively. Response data for each excitation was obtained by averaging the results from three repeated impact excitations. The test excitation and response signals were collected by using the INV3020C data acquisition system with 20 channels and the frequency response function was obtained. The measurements were checked and validated using the coherence function. The vibration mode shapes and their natural frequencies of the first three vibration modes of the test floors were analyzed by using the DASP-V10 analysis software available at the China Orient Institute of Noise and Vibration.

3.2. Testing of the Transfer Function. Vibration transfer function tests on the floors were conducted to study the propagation attenuation characteristics of the vibration input signal for different floor configurations by adding transverse elements. The transfer function of the vibration mainly reflects the transmission characteristics of the vibration response in the system to the vibration excitation, which depends on the characteristics of the system itself and is not related to the input signal. If the input and output of the system are $x(t)$ and $y(t)$, the vibration transfer function is defined as the ratio of the Fourier transform $Y(\omega)$ of the output signal to the Fourier transform $X(\omega)$ of the input signal, with the mathematical expression as shown in

$$
H_{x y}(\omega)=\frac{Y(\omega)}{X(\omega)} .
$$

Six acceleration transducers were arranged at the midspan of six-floor joists, shown in Figure 5, where $V$ is the excitation location, while P1, P2, P3, P4, P5, and P6 are the response measurement locations. $\mathrm{P} 1$ is adjacent to $V$, where the P1 response represents the input signal of the $V$ excitation. When impacted at point $V$ with the exciting hammer, 


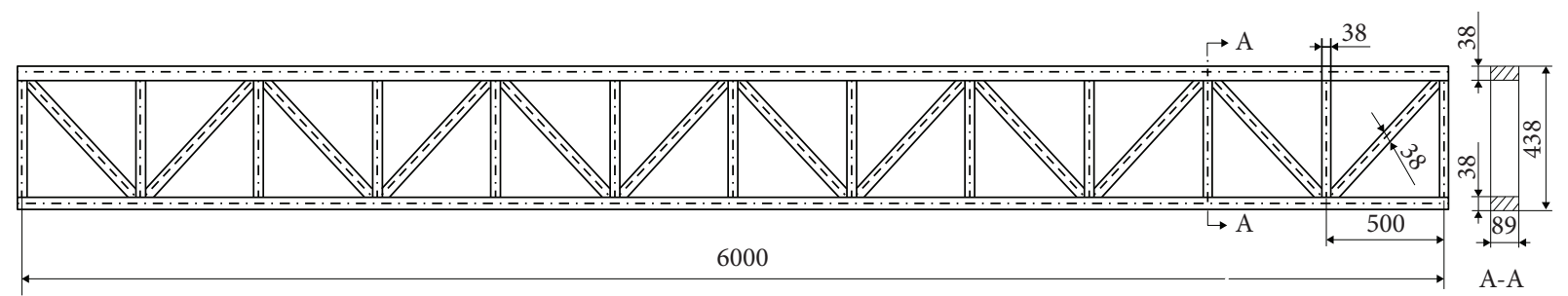

FIgURE 1: Typical parallel flange timber truss.

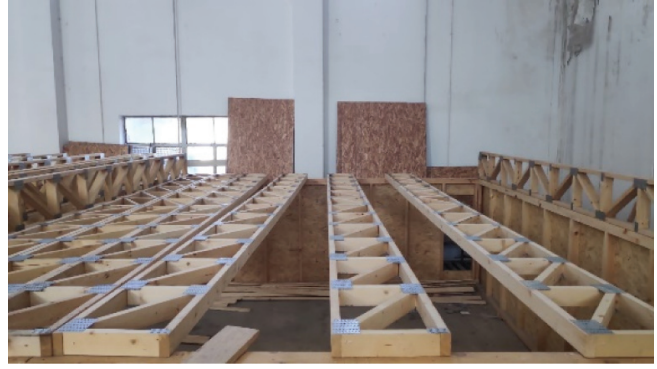

(a)

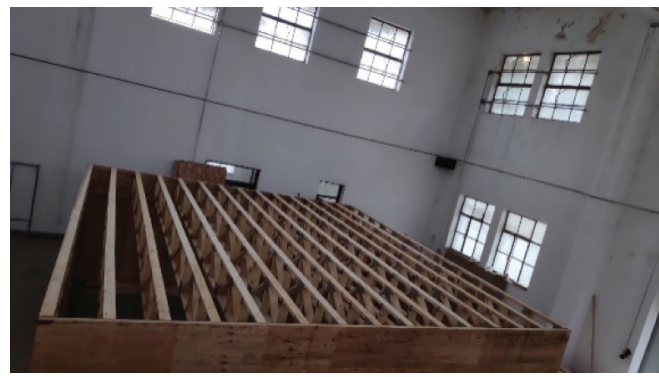

(c)

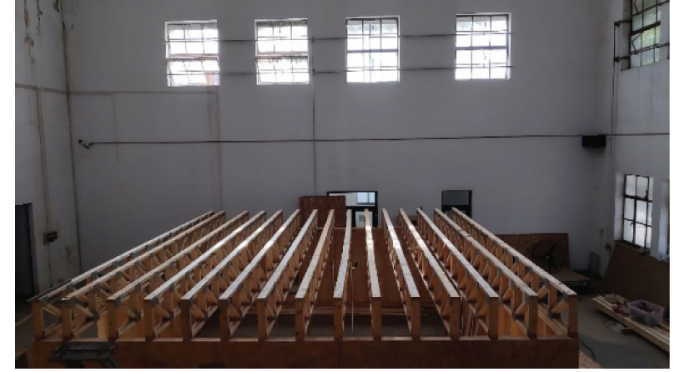

(b)

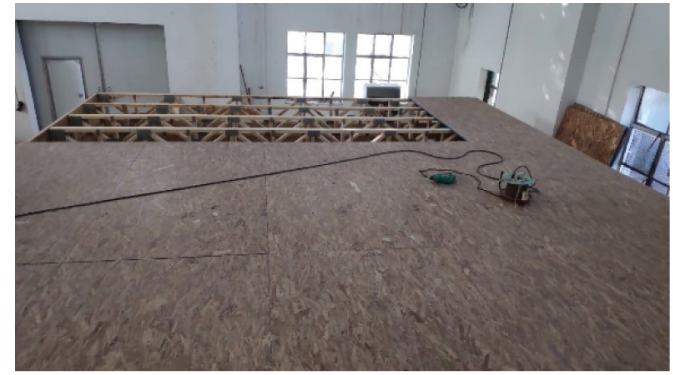

(d)

FIGURE 2: Construction process of the test floors.

the input signal at point P1 on the test floors and the output signals at points P2-P6 were measured.

\section{Results and Discussion}

4.1. Effects of the Strongbacks and Strappings on the Vibration Modes of the Test Floors. The first three vibration mode shapes of the test floors are presented in Figure 6. Although the test floors had different strongbacks/strappings or different joist spacings, all of them showed vertical vibrations and the first three vibration mode shapes among them were the same. The first vibration mode showed that the entire test floors sustained one vibration wave along the floor width direction. The second vibration mode exhibited two alternate vertical vibration waves of two adjacent floor parts along the floor width direction (perpendicular to the joist direction). Different from the first two vibration modes, the third vibration mode shape showed a three-part fluctuation along the floor width direction (the middle part and both edge parts with alternate vibrations).

The first three natural frequency components of the test floors with different installed strongbacks are shown in Figure 7. For the test floors with the joist spacing of $400 \mathrm{~mm}$, the fundamental natural frequencies of Floors T1-1 to T1-5 varied from $14.8 \mathrm{~Hz}$ to $15 \mathrm{~Hz}$ with the increase of the strongbacks. The second natural frequencies increased from $17.8 \mathrm{~Hz}$ to $20.6 \mathrm{~Hz}$, while the third natural frequencies increased from $21.0 \mathrm{~Hz}$ to $27.4 \mathrm{~Hz}$. One strongback at the midspan (Floor T1-2) only increased the second mode frequency by $1 \mathrm{~Hz}$ and the third mode frequency by $2.4 \mathrm{~Hz}$, but almost no differences in the fundamental natural frequencies were observed, compared to the test floor without strongbacks (Floor T1-1). Two and three strongbacks at the midspan (Floor T1-3 and Floor T1-4) increased the second mode frequency by $1 \mathrm{~Hz}$ and $2.3 \mathrm{~Hz}$, respectively; meanwhile, they increased the third mode frequency by $4.3 \mathrm{~Hz}$ and $4.4 \mathrm{~Hz}$. Four strongbacks (Floor T1-5) increased the second mode frequency by $2.8 \mathrm{~Hz}$ and the third mode frequency by $6.4 \mathrm{~Hz}$, while no differences in the fundamental natural frequency happened, compared to Floor T1-1.

For the test floors with the joist spacing of $600 \mathrm{~mm}$, the fundamental vibration frequencies of Floors T3-1 to T3-5 slightly increased from $12.2 \mathrm{~Hz}$ to $12.9 \mathrm{~Hz}$ with the increase of the number of strongbacks. The second natural frequencies increased from $16.9 \mathrm{~Hz}$ to $17.7 \mathrm{~Hz}$, while the third natural frequencies increased from $17.5 \mathrm{~Hz}$ to $21.7 \mathrm{~Hz}$. One 
TABLE 1: Physical and mechanical properties of the adopted oriented strand boards (OSBs).

\begin{tabular}{lccccc}
\hline Thickness $(\mathrm{mm})$ & $\mathrm{MOR}_{\|}(\mathrm{MPa})$ & $\mathrm{MOR}_{\perp}(\mathrm{MPa})$ & $\mathrm{MOE}_{\|}(\mathrm{MPa})$ & $\mathrm{MOE}_{\perp}(\mathrm{MPa})$ & $\mathrm{Density}\left(\mathrm{kg} / \mathrm{m}^{3}\right)$ \\
\hline 15 & 35.1 & 20.5 & 4280 & 2080 & \\
18 & 35.3 & 22.6 & 5240 & 2400 & 650 \\
\hline
\end{tabular}

Note. MOE and MOR are the modulus of elasticity and the modulus of rupture, respectively; $\|$ and $\perp$ denote parallel (major strength direction) and perpendicular (minor strength direction) to the length direction, respectively.

TABLE 2: Configuration details of the base test floors.

\begin{tabular}{lccc}
\hline Floor type & Joist spacing $(\mathrm{mm})$ & Number of strongback rows & Strapping spacing (mm) \\
\hline T1-1 & 400 & 0 & - \\
T1-2 & 400 & 1 & - \\
T1-3 & 400 & 2 & - \\
T1-4 & 400 & 3 & - \\
T1-5 & 400 & 4 & 600 \\
T1-6 & 400 & 0 & 400 \\
T1-7 & 400 & 0 & 300 \\
T1-8 & 400 & 0 & - \\
T3-1 & 600 & 0 & - \\
T3-2 & 600 & 1 & - \\
T3-3 & 600 & 2 & - \\
T3-4 & 600 & 3 & - \\
T3-5 & 600 & 4 & 600 \\
T3-6 & 600 & 0 & 400 \\
T3-7 & 600 & 0 & 300 \\
T3-8 & 600 & 0 & \\
\hline
\end{tabular}

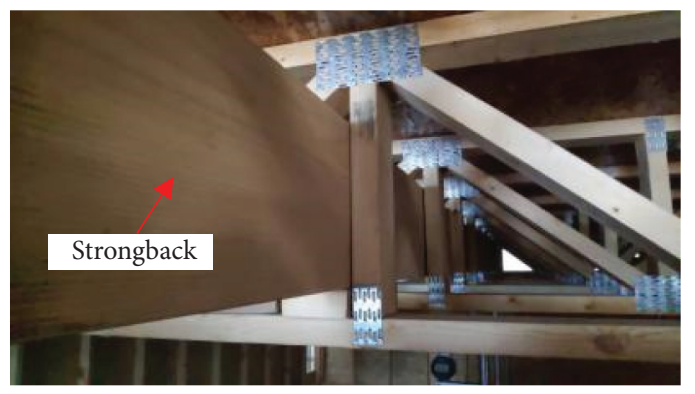

(a)

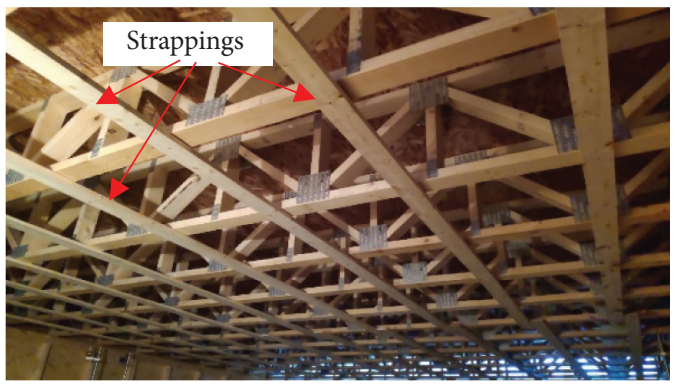

(b)

FIGURE 3: Installation of the bracing elements of strongbacks and strappings onto the test floors. (a) Strongbacks. (b) Strappings.

strongback at the midspan (Floor T3-2) decreased the frequencies by $0.4 \mathrm{~Hz}$ and $0.2 \mathrm{~Hz}$ for the first and second modes, but increased the frequency by $2.5 \mathrm{~Hz}$ for the third mode, compared to the reference test floor without strongbacks (Floor T3-1). Four strongbacks (Floor T3-5) increased the frequency by $0.6 \mathrm{~Hz}$ for the second mode and by $4.2 \mathrm{~Hz}$ for the third mode, while the bracing elements decreased the fundamental frequency by only $0.1 \mathrm{~Hz}$, compared to Floor T3-1.

It can be seen that the fundamental vibration frequency for the first mode sustained no changes with the increase of strongbacks for the T1 and T3 test floor series. It was further proved that the fundamental vibration frequency was dominated primarily by the stiffness parallel to the joist direction $[3,6,14,15]$. The bracing elements of strongbacks obviously raised the second and third natural frequencies [21]. The floors with the joist spacing of $400 \mathrm{~mm}$ sustained a greater change in the natural frequencies, compared with those with the joist spacing of $600 \mathrm{~mm}$. This greatly widened the spacing of two adjacent natural frequencies, which was considered to induce human discomfort because of the development of beat frequencies [14]. Moreover, with the increase of the joist spacing for the same floor span, the natural frequencies of the test floors sustained decreases accordingly. The stiffness of each truss along to joist direction was about the same, but the system stiffness was reduced due to the decrease of the ratio of the span to the width. As shown in Figure 8, the static deflections at the center of the $\mathrm{T} 1$ test floor series were obviously smaller than these of the T3 test floor series. 


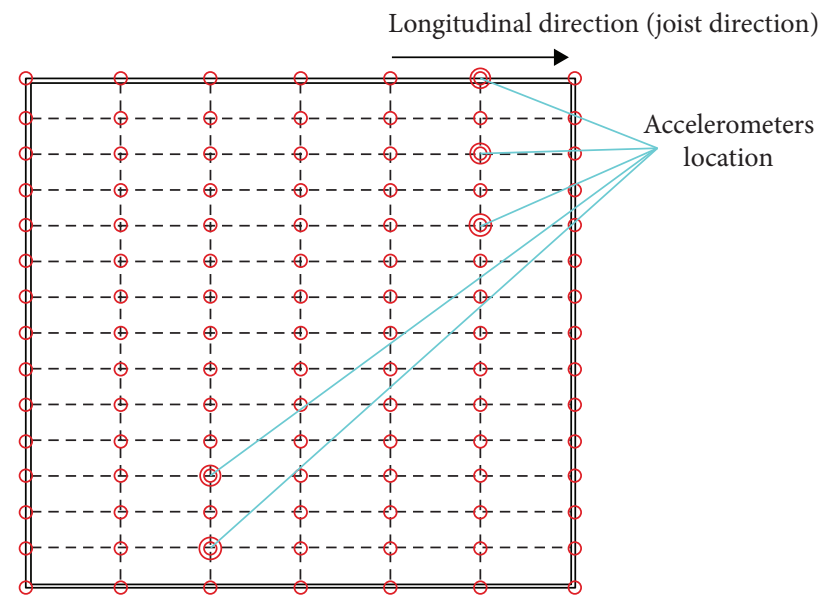

FIgURE 4: The measurement grid of the test floors and response measurement locations.

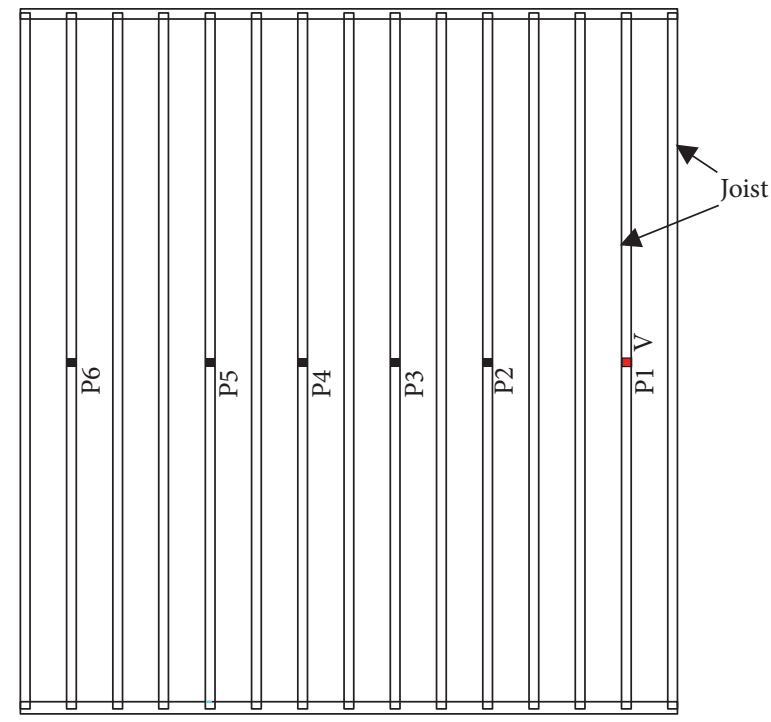

FIGURE 5: Locations of the hammer impact excitation and response measurements.

The changes of the first three natural frequency distributions for the test floors with and without strappings are shown in Figure 9. For the test floors with the joist spacing $400 \mathrm{~mm}$, the fundamental natural frequencies of Floors T1-6 to T1-8 decreased from $15.0 \mathrm{~Hz}$ to $14.7 \mathrm{~Hz}$ with the decrease of the strapping spacing. The second natural frequencies increased from $18.8 \mathrm{~Hz}$ to $19.2 \mathrm{~Hz}$, while the third natural frequencies varied from $21.5 \mathrm{~Hz}$ to $25 \mathrm{~Hz}$. For the test floors with the joist spacing of $600 \mathrm{~mm}$, the fundamental natural frequencies of Floors T3-6 to T3-8 increased from $12.6 \mathrm{~Hz}$ to 12.9 $\mathrm{Hz}$ with the decrease of the strapping spacing, while the second and third natural frequencies varied from $16.3 \mathrm{~Hz}$ to $17 \mathrm{~Hz}$ and from $17.5 \mathrm{~Hz}$ to $18.0 \mathrm{~Hz}$, respectively. Small changes in their frequencies from T3-6 to T3-8 floors were due to small differences in their stiffnesses as shown in Figure 10. Accordingly, the natural frequencies of the test floors with the $400 \mathrm{~mm}$ joist spacing were greater than those of the test floors with the $600 \mathrm{~mm}$ joist spacing. The decrease in the system stiffness contributed to the case. For the test floors with $400 \mathrm{~mm}$ and $600 \mathrm{~mm}$ joist spacings, their fundamental natural frequencies for the first vibration mode almost were unchanged before and after the installation of strappings. The second natural frequencies for the test floors with the $400 \mathrm{~mm}$ joist spacing increased by a few $\mathrm{Hz}$ after strappings were installed, while the second natural frequencies slightly decreased for the test floors with the $600 \mathrm{~mm}$ joist spacing. However, the second natural frequencies for the test floors with the $400 \mathrm{~mm}$ joist spacing had no significant changes for the strapping spacings of $600 \mathrm{~mm}$, $400 \mathrm{~mm}$, and $300 \mathrm{~mm}$. The increase of rows of strappings just had an obvious influence on the third natural frequencies for the test floors with the joist spacing of $400 \mathrm{~mm}$ and caused a smaller effect on both the second and third natural frequencies for the test floors with the joist spacing of $600 \mathrm{~mm}$.

Similar to other floors, the main structural changes of the metal-plate-connected timber truss joist floors including the spacing of the joists or the system stiffness can affect the natural frequencies, static deflections, and dynamic 


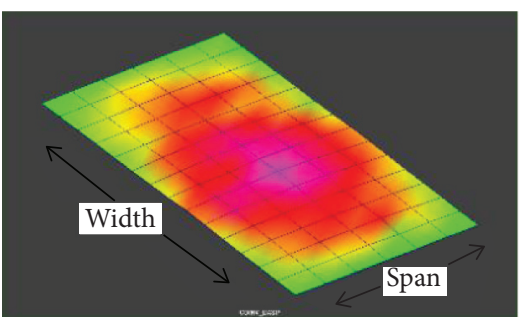

(a)

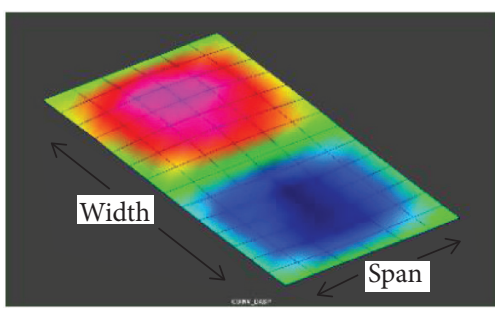

(b)

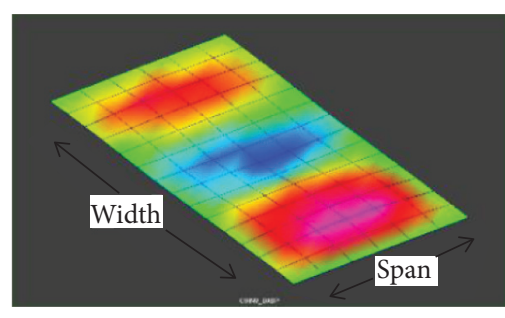

(c)

FIgURE 6: First three vibration mode shapes of the test floors. (a) Mode 1. (b) Mode 2. (c) Mode 3.

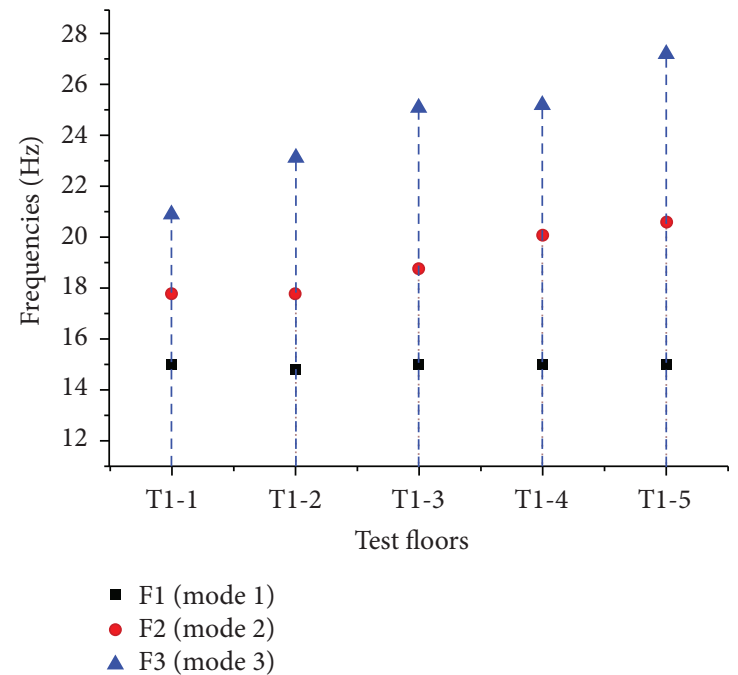

(a)

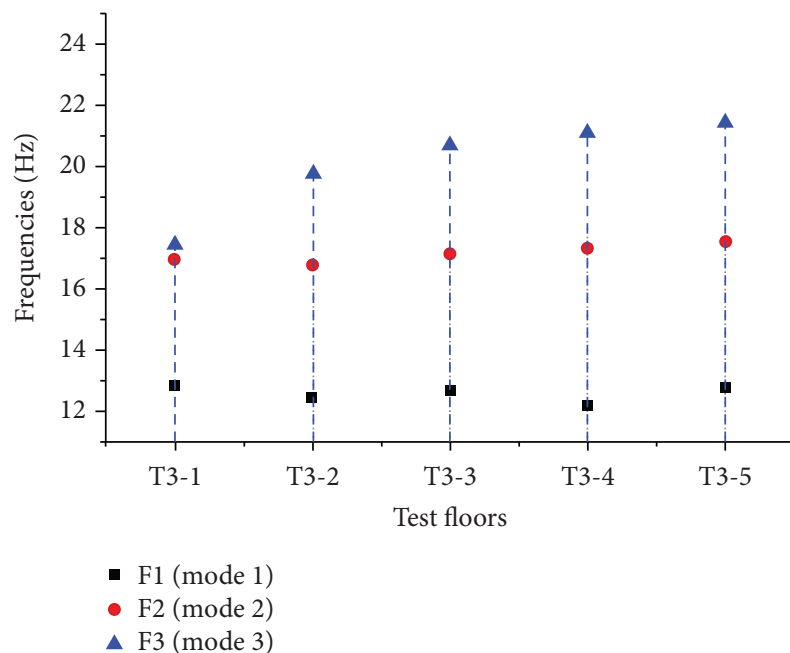

(b)

FiguRE 7: First three natural frequencies of the test floors with the joist spacings of $400 \mathrm{~mm}$ and $600 \mathrm{~mm}$ before and after the installation of strongbacks.

responses. Moreover, the secondary structural changes including the amount and the location of strongbacks or strappings can also improve the vibration performances of the metal-plate-connected timber truss joist floors.

4.2. Effects of Strongbacks and Strappings on the Floor Vibration Transfer. When considering combined vibration endurance and transfer strength, the targeted frequency range from $5 \mathrm{~Hz}$ to $35 \mathrm{~Hz}$ was selected for the vibration transfer function tests. The coherence functions were determined at the resonance frequency according to the correlation between the excitation and response signals and all coherence coefficients were close to 1 . This indicated that the vibration responses were better excited by the input excitation and the test results were validated. The transfer functions at each location along the midspan direction of the test floors with the $400 \mathrm{~mm}$ joist spacing before and after the installation of strongbacks were calculated and synthesized, as shown in Figure 11. In general, the responses were attenuated with the increasing distance from the excitation source due to the geometrical damping, caused by the spreading of the vibration energy over a larger area, and the material damping, caused by the dissipation of the energy in these timber members, although the system damping ratios were below $10 \%$. For Floor T1-2, one strongback put at the midspan caused the strong vibration energy to happen at the frequency of about $20 \mathrm{~Hz}$, not only near the excitation location but also in the area far from the excitation location. Moreover, this seemed to defuse the vibration energy between 30 and $35 \mathrm{~Hz}$. The location where strong vibration energy happened on Floor T1-3 presented a similar case with the vibration mode shape. The strongback distribution on Floor T1-4 caused the vibration energy to have a $500 \mathrm{~mm}$ wide gap at a distance of about $2 \mathrm{~m}$ from the excitation point but it appeared in a bigger area farther away. Floor T1-5 had just an obvious transmission path at about $21 \mathrm{~Hz}$, caused by its second vibration mode. It can be thought that the vibration transfer is closely related to floor construction details, which altered the vibration natural frequencies [25].

The transfer functions at each location along the midspan direction of the test floors with the $600 \mathrm{~mm}$ joist spacing before and after the installation of strongbacks were calculated and synthesized, as shown in Figure 12. It can be seen that, at second or higher natural vibration frequencies, the test floors had a strong vibration energy transfer path. At the third natural 


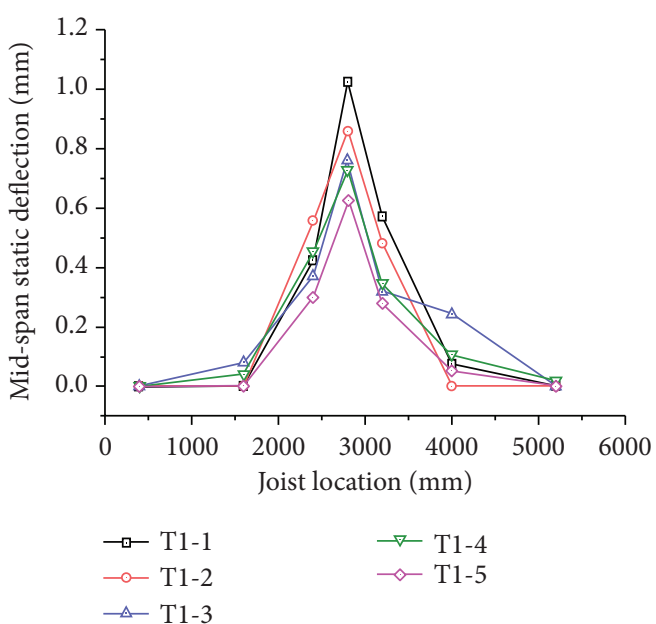

(a)

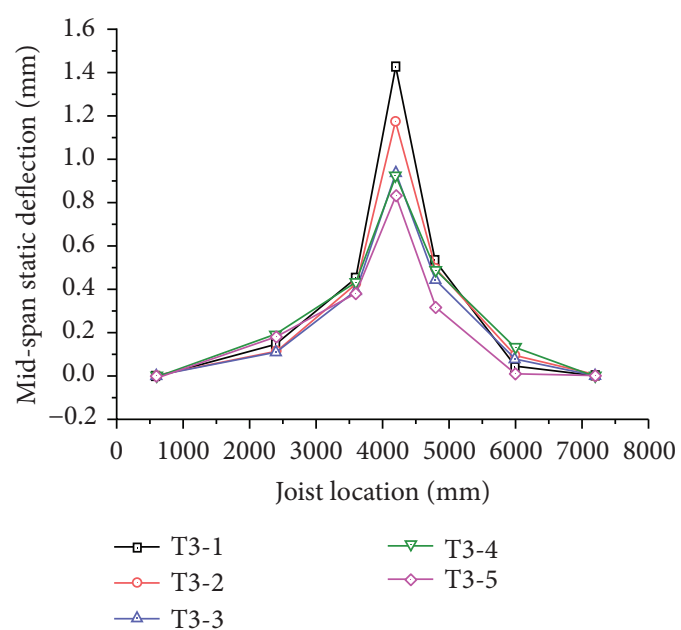

(b)

Figure 8: Midspan static deflections of the test floors before and after installation of strongbacks under the concentrated load of $1 \mathrm{kN}$ at the floor center.

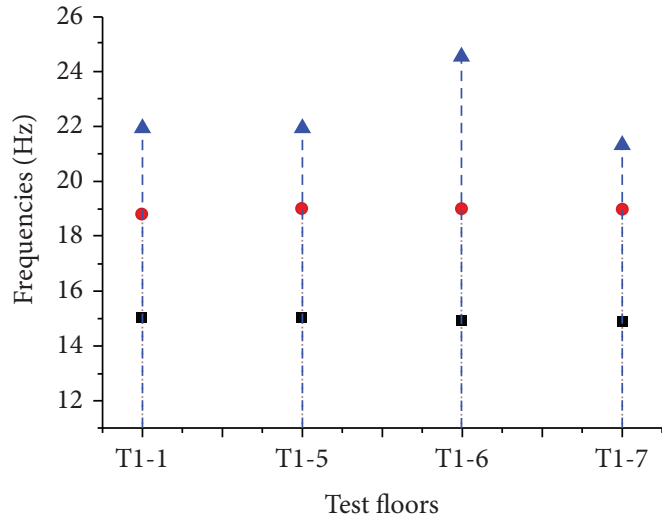

- F1 (mode 1$)$

- F2 (mode 2)

- F3 (mode 3$)$

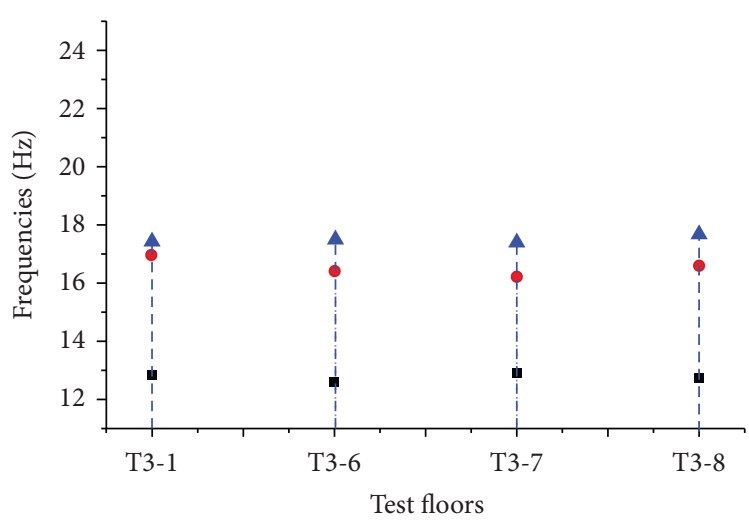

- F1 (mode 1$)$

- F2 (mode 2$)$

- F3 (mode 3 )

(a)

(b)

FIGURE 9: The first three natural frequencies of the test floors with the joist spacings of $400 \mathrm{~mm}$ and $600 \mathrm{~mm}$ before and after the installation of strappings.

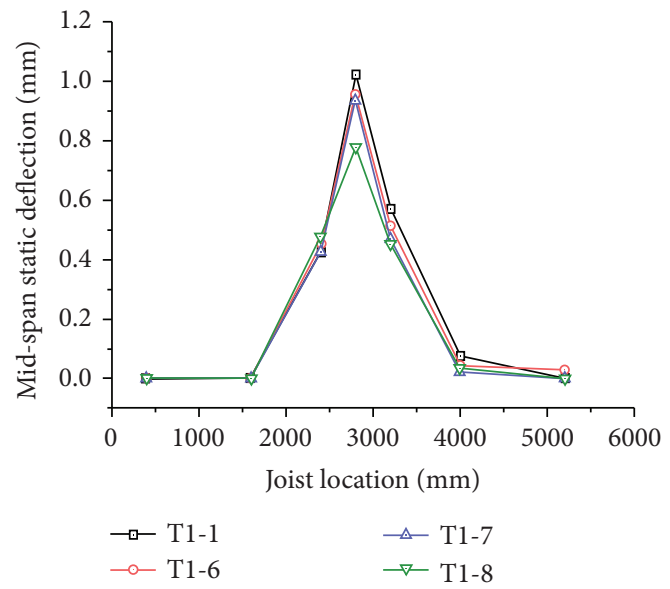

(a)
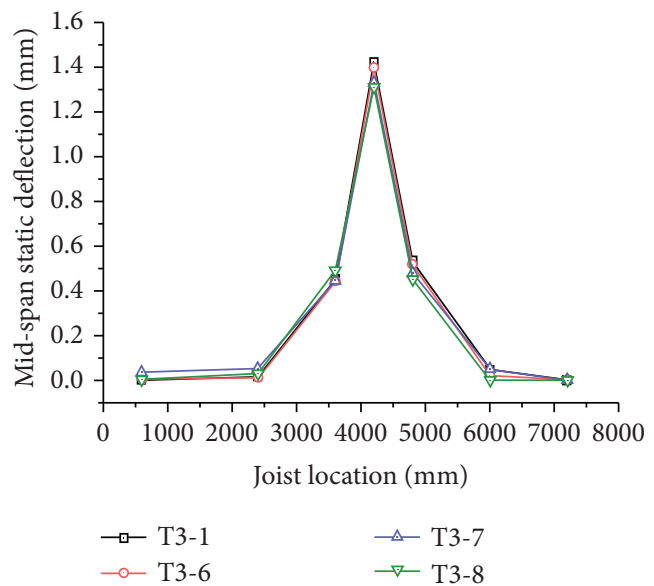

(b)

Figure 10: Midspan static deflections of the test floors with the joist spacings of $400 \mathrm{~mm}$ and $600 \mathrm{~mm}$ before and after installation of strappings under the concentrated load of $1 \mathrm{kN}$ at the floor center. 


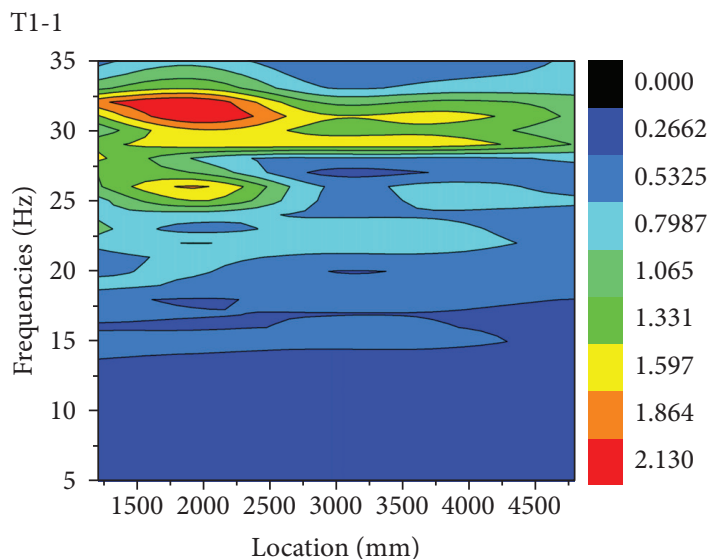

(a)

T1-3

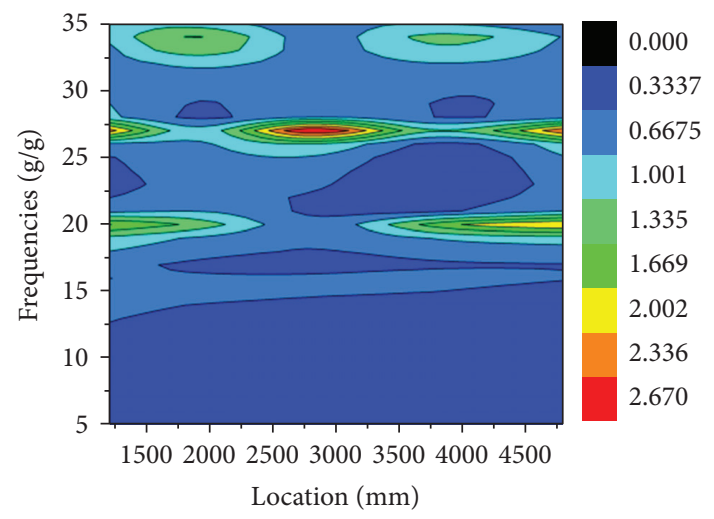

(c)

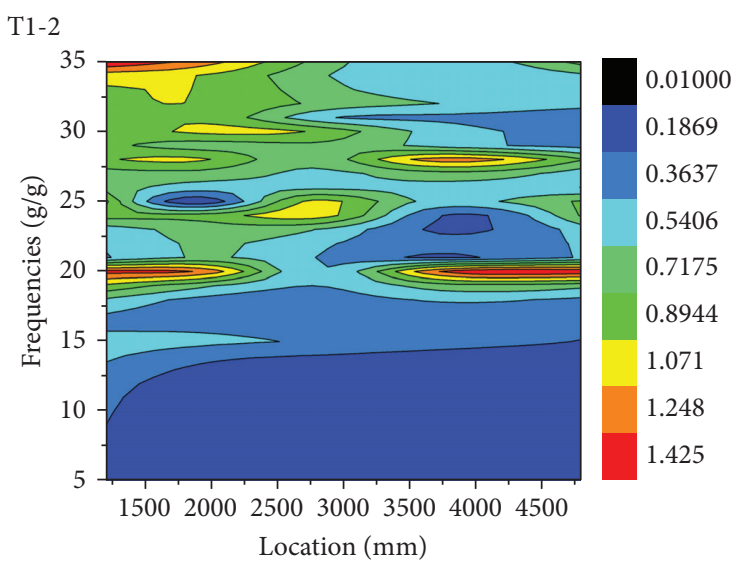

(b)

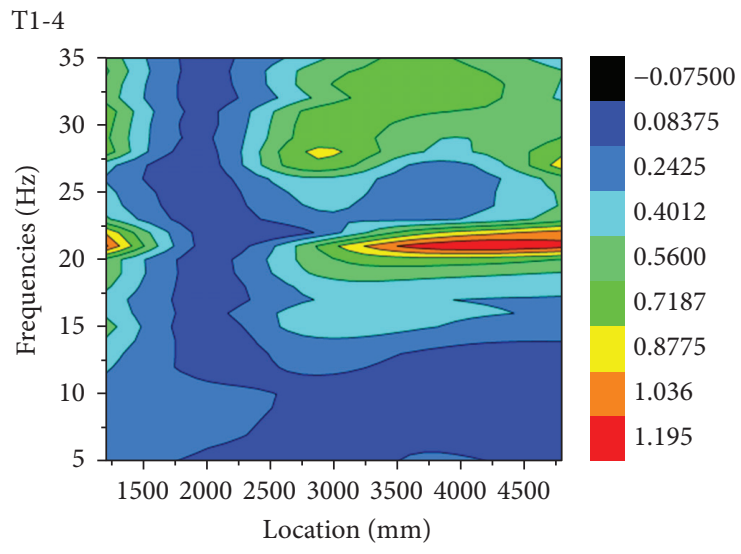

(d)

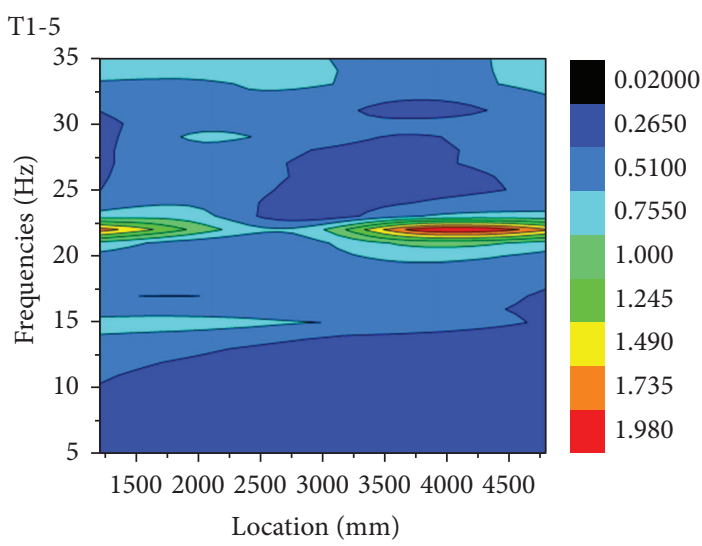

(e)

Figure 11: Transfer functions of the T1 test floors with the $400 \mathrm{~mm}$ joist spacing.

frequencies, the test floors had the greatest vibration amplitude in one area for Floor T3-1, two areas for Floors T3-2 and T3-5, and three areas for Floors T3-3 and T3-4. With the installation of strongbacks, the floor construction changed perpendicular to the joist direction and the strongback members played a bridging role in the vibration transmission. The vibration energy is transferred over a distance of more than $7 \mathrm{~m}$ by the bridge of strongbacks. After adding one or two strongbacks, the floors can transmit the strongest vibration energy; see Floors T3-2 and T3-3.
The transfer functions at each location along the midspan direction of the test floors with the $400 \mathrm{~mm}$ and $600 \mathrm{~mm}$ joist spacings before and after the installation of strappings were calculated and synthesized, as shown in Figures 13 and 14. For the test floors with the $400 \mathrm{~mm}$ joist spacing, it can be seen that all the test floors had a strong vibration energy transfer path at frequencies above $20 \mathrm{~Hz}$, especially this becoming more significant for the third natural frequency. The strappings were helpful to transmit the vibration energy at low frequencies below $20 \mathrm{~Hz}$. The 


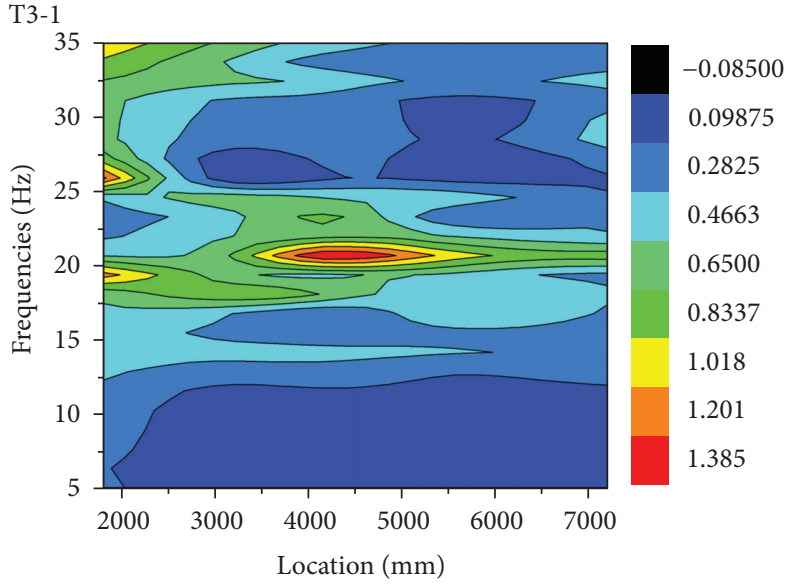

(a)

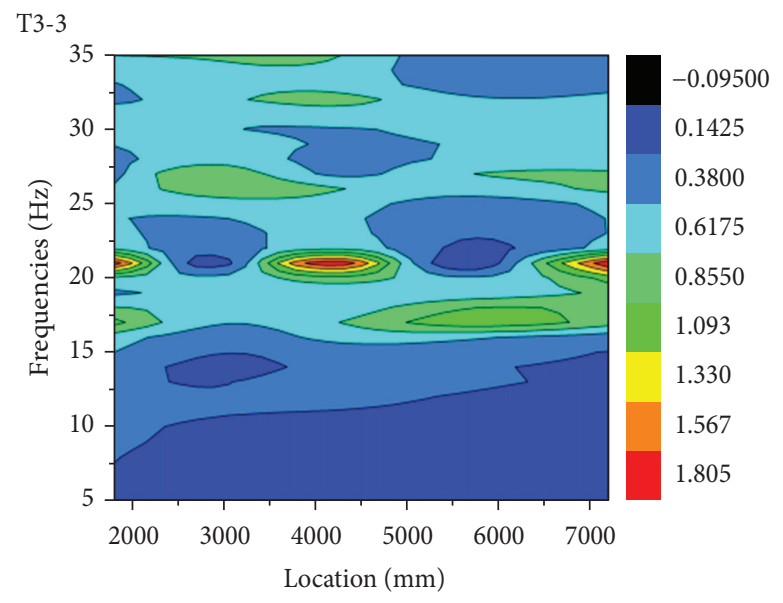

(c)

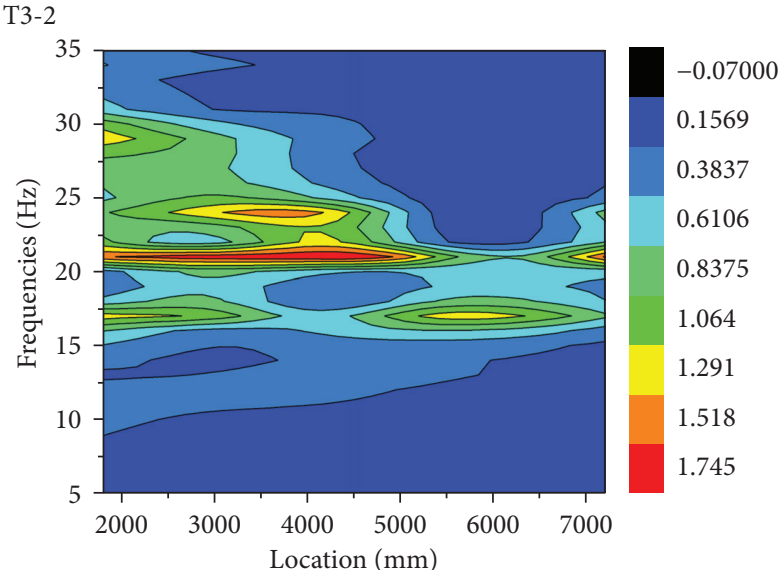

(b)

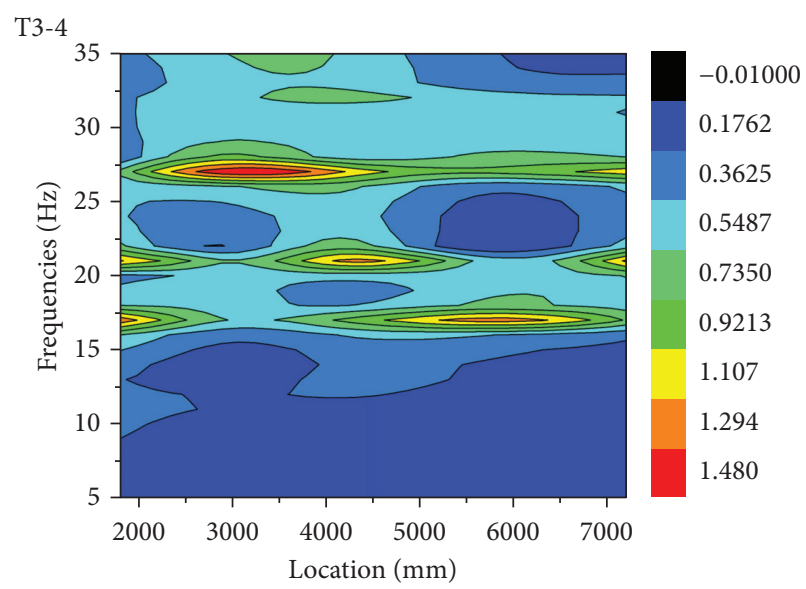

(d)

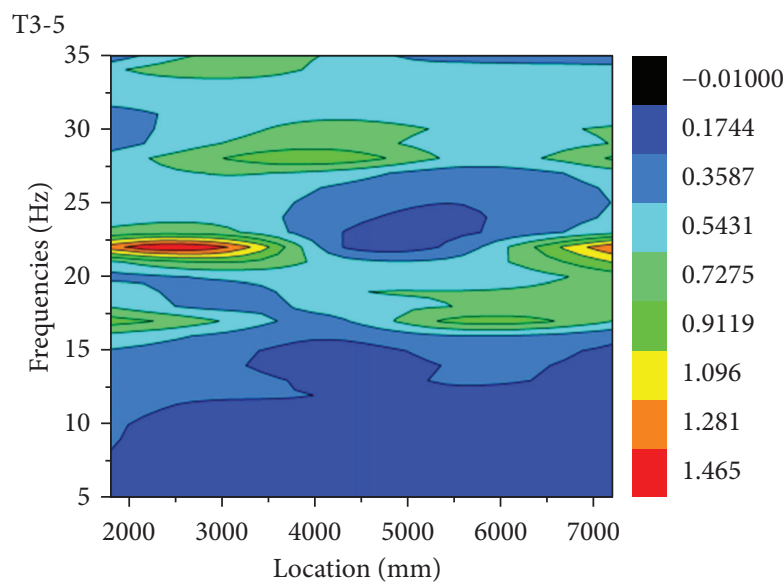

(e)

Figure 12: Transfer functions of the T3 test floors with the $600 \mathrm{~mm}$ joist spacing.

strong vibration energy transfer paths, which behaved in the third vibration mode shape, appeared at about $22 \mathrm{~Hz}$ with the decrease of the strapping spacing. The vibration transfer energy at about $25 \mathrm{~Hz}$ frequency for the floors with the strapping spacing of $600 \mathrm{~mm}$ was attenuated when the floors changed with the strapping spacings of $300 \mathrm{~mm}$ and $400 \mathrm{~mm}$. For the test floors with the $600 \mathrm{~mm}$ joist spacing, the vibration transfer bands at the frequency range from $15 \mathrm{~Hz}$ to $30 \mathrm{~Hz}$ were widened and increased. However, the maximum vibration amplitude, when existing in the strongest vibration energy at some frequency, was effectively weakened to some extent.

The amplitude distribution of the floor vibration transfer function was closely related to the vibration frequency and 


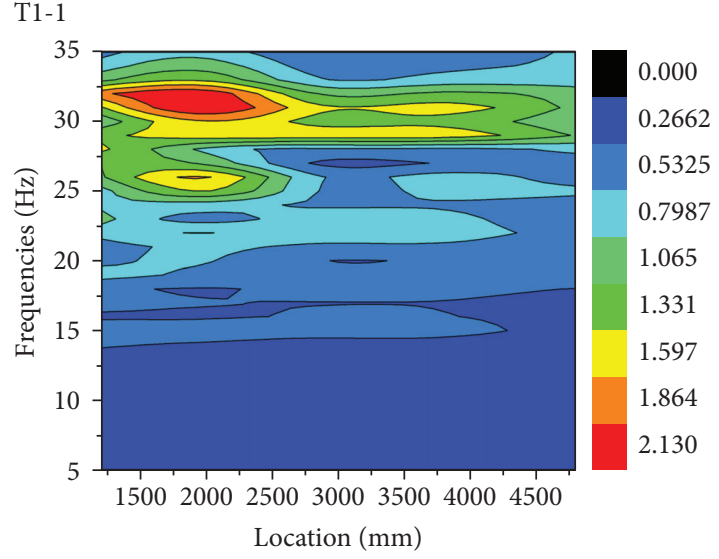

(a)

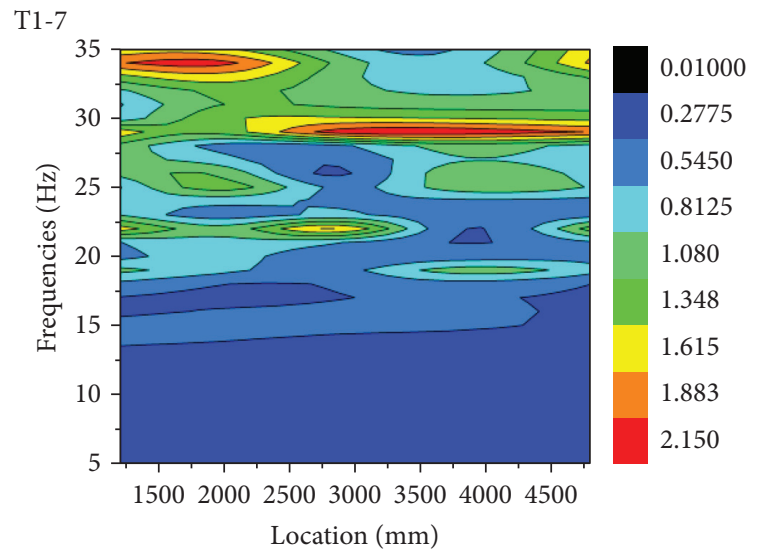

(c)
T1-6

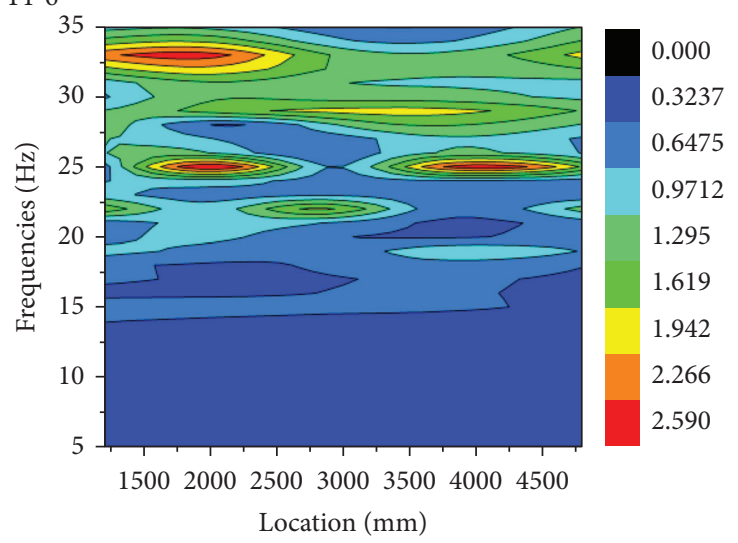

(b)

T1-8

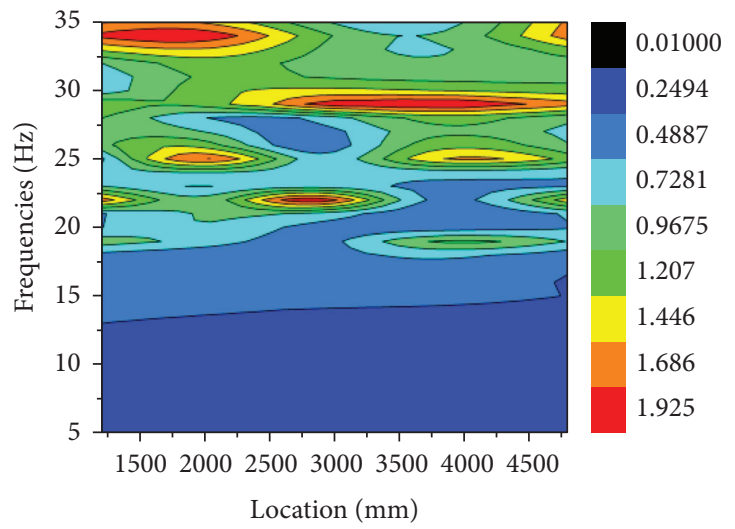

(d)

Figure 13: Transfer functions of the T1 test floors with the $400 \mathrm{~mm}$ joist spacing.

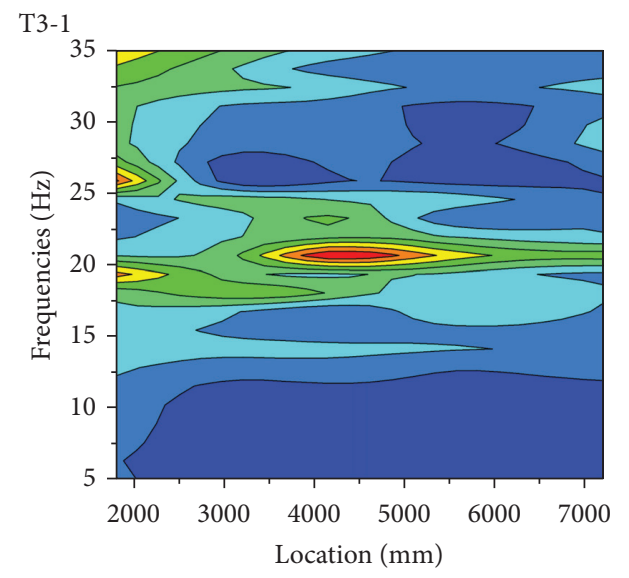

(a)

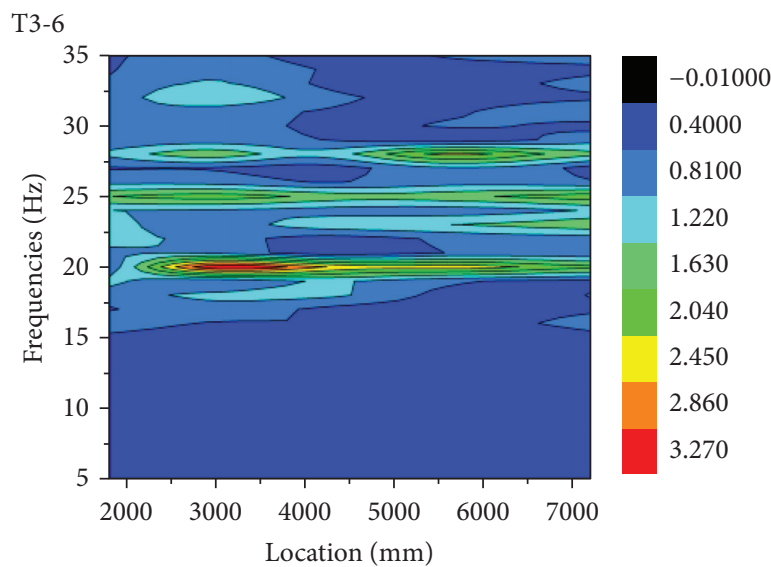

(b)

Figure 14: Continued. 


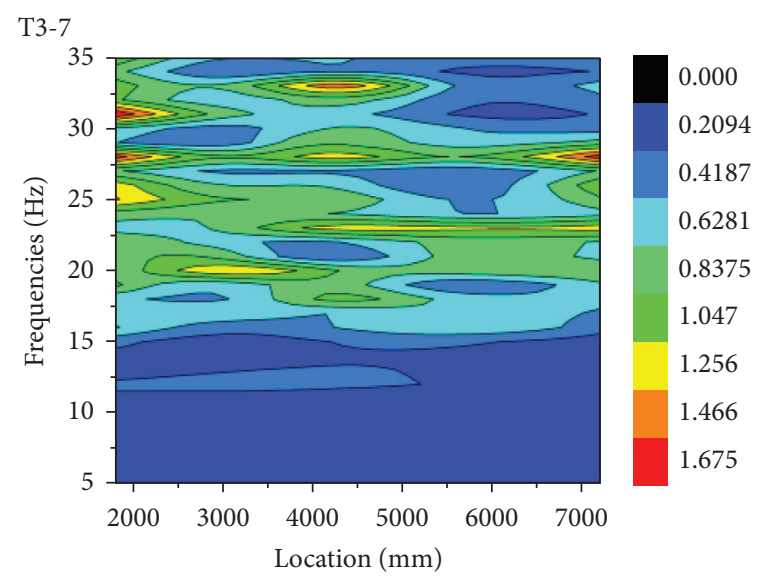

(c)

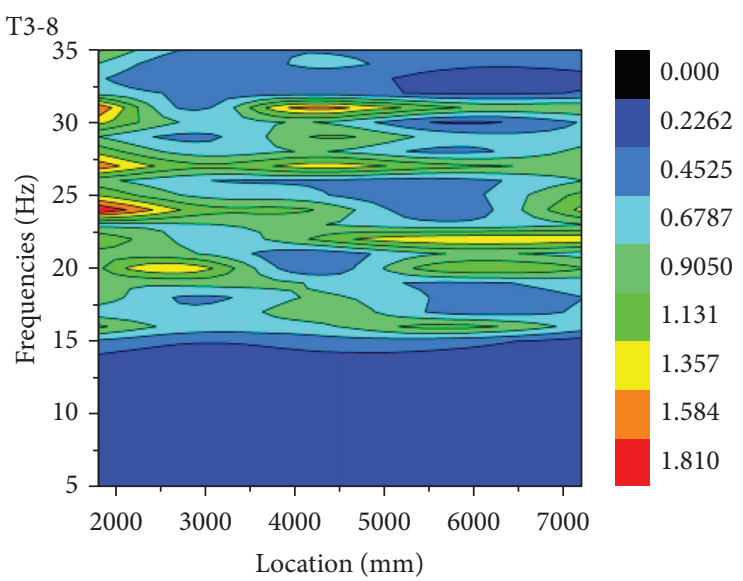

(d)

Figure 14: Transfer functions of the T3 test floors with the $600 \mathrm{~mm}$ joist spacing.

vibration mode of the test floors. The more the number of bracing elements, the more the scattered distribution of the peak amplitude for the vibration transmission in the interested frequency band. The frequency scope in which the stronger vibration transfer happened is above $15 \mathrm{~Hz}$. The limit frequency of $15 \mathrm{~Hz}$ was lower than the second and third natural vibration frequencies. The vibration energy supporting the vibration amplitude can transfer a longer distance and cover the full width of the test floors. The bracing elements can also change the location where the peak vibration amplitude appears. The application of mitigation measurements can relieve the strong vibration response which may happen at some location or some frequency $[26,27]$.

\section{Conclusions}

In this paper, the vibration modes and transfer functions of sixteen metal-plate-connected timber truss joist floors with the nominal span of $6 \mathrm{~m}$ were tested and the relationships among the bracing elements as secondary structural components, natural frequency changes, and vibration transmissions were analyzed. The main conclusions can be drawn as follows:

(1) The fundamental natural frequencies of the metalplate-connected timber truss joist floors with the $400 \mathrm{~mm}$ joist spacing were about $15 \mathrm{~Hz}$, while the frequencies of the floors with $600 \mathrm{~mm}$ joist spacing were about $12.5 \mathrm{~Hz}$. The second natural frequencies of the metal-plate-connected timber truss joist floors with $400 \mathrm{~mm}$ and $600 \mathrm{~mm}$ joist spacings were above $17 \mathrm{~Hz}$ and $16 \mathrm{~Hz}$, respectively. The third natural frequencies of the metal-plate-connected timber truss joist floors with $400 \mathrm{~mm}$ and $600 \mathrm{~mm}$ joist spacings were above $19 \mathrm{~Hz}$ and $17 \mathrm{~Hz}$, respectively.

(2) The second and third natural frequencies of the floors could be significantly changed by adding the bracing elements of strongbacks and strappings. For the test floors with the $400 \mathrm{~mm}$ joist spacing, the second natural frequencies increased by $5.6 \%$ to $15.7 \%$ with the increase of the number of strongbacks, and the corresponding third natural frequencies increased by $11.4 \%$ to $30.5 \%$. With the decrease of the strapping spacing, the second and third natural frequencies did not show evident changing trends.

(3) Main transmission paths of the vibration energy in the across-joist direction depended on natural vibrations of the floors caused by the input excitation. The frequency scope in which the stronger vibration transfer happened was generally above $15 \mathrm{~Hz}$. The more the number of bracing elements, the more the scattered distribution of the peak amplitude for the vibration transmission in the interested frequency band. The bracing elements effectively changed the locations for the peak vibration amplitudes and their vibration intensities.

(4) The bracing elements as secondary structural components of the floors enhanced the stiffness in the across-joist direction and altered the vibration transmission paths. The stiffnesses of the floor systems influenced their vibration modes and vibration transmissions. Effective mitigation measurements should be selected to relieve the strong vibration responses at some locations for some frequency.

\section{Data Availability}

Some or all data, models, or codes generated or used during the study are available from the corresponding author upon request.

\section{Conflicts of Interest}

The authors declare that they have no conflicts of interest.

\section{Acknowledgments}

This project was supported by the National Natural Science Foundation of China under Grant no. 31770603. 


\section{References}

[1] L. J. Hu, Y. H. Chui, and D. M. Onysko, "Vibration serviceability of timber floors in residential construction," Progress in Structural Engineering and Materials, vol. 3, no. 3, pp. 228-237, 2001.

[2] N. H. Abd Ghafar, I. Z. Shamsul Kamar, D. E. C. Yeoh, and H. B. Koh, "Walking induced floor vibration on glulam timber floor," in Proceedings of AWAM International Conference on Civil Engineering, vol. 53, Penang, Malaysia, 2020.

[3] J. D. Dolan, T. M. Murray, J. R. Johnson, D. Runte, and B. C. Shue, "Preventing annoying wood floor vibrations," Journal of Structural Engineering, vol. 125, no. 1, pp. 19-24, 1999.

[4] Y. H. Chui, Vibrational performance of wooden floors in domestic dwellings, Ph.D. thesis, Brighton Polytechnic, Brighton, UK, 1987.

[5] L. J. Hu, Serviceability Design Criteria for Commercial and Multifamily Floors, Canadian Forest Service Report No. 4, Forintek Canada Corp, Sainte-Foy, Canada, 2000.

[6] J. R. Johnson, "Vibration acceptability in wood floor systems," Master's thesis, Virginia Polytechnic Institute, Blacksburg, VA, USA, 1994.

[7] K. Jarnero, Vibrations in timber floors: dynamic properties and human perception, Ph.D. thesis, Linnaeus University, Vaxjoe, Sweden, 2014.

[8] I. Smith, S. Thelandersson, and H. J. Larsen, "Vibration of timber floors-serviceability aspects," Timber Engineering, pp. 241-266, Wiley, Chichester, UK, 2003.

[9] J. Weckendorf, Dynamic response of structural timber flooring systems, Ph.D. thesis, Edinburgh Napier University, Edinburgh, UK, 2009.

[10] J. Weckendorf, G. Hafeez, G. Doudak et al., "Investigations of nature of floor vibration serviceability problems in wood lightframe buildings," Journal of Performance of Constructed Facilities, vol. 28, no. 6, Article ID A4014003, 2014.

[11] Y. H. Chui and I. Smith, "A dynamic approach for timber floor design," New Zealand Journal of Timber Construction, vol. 8, no. 1, pp. 9-10, 1990.

[12] L. J. Hu and Y. H. Chui, "A new design method to control vibration induced by footsteps in timber floor," Technical report, Forintek Canada Corp, Sainte-Foy, Canada, 2000.

[13] D. M. Onysko, Deflection Serviceability Criteria for Residential Floors. Canadian Forestry Service Report No. 17, Forintek Canada Corporation, Ottawa, Canada, 1988.

[14] S. Ohlsson, "Serviceability criteria-especially floor vibration criteria," in Proceedings of 1991 International Timber Engineering Conference, London, UK, 1991.

[15] I. Smith and Y. H. Chui, "Design of lightweight wooden floors to avoid human discomfort," Canadian Journal of Civil Engineering, vol. 15, no. 2, pp. 254-262, 1988.

[16] K. Jarnerö, A. Brandt, and A. Olsson, "Vibration properties of a timber floor assessed in laboratory and during construction," Engineering Structures, vol. 82, pp. 44-54, 2015.

[17] L. J. Hu and Y. Tardif, "Effects of partition walls on vibration performance of engineered wood floors," in Proceedings of the 1st International RILEM Symposium on Timber Engineering, Stockholm, Sweden, September 1999.

[18] G. P. C. Van Oosterhout, R. Donkervoort, and J.-W. G. Van de Kuilen, "Vibration measurements on timber frame floors," in Proceedings of the Cost Action E5 Workshop of Construction, Structural and Serviceability Aspects of MultiStory Timber Frame Buildings, Building Research Establishment (BRE), Liverpool, UK, June 1998.
[19] J. Weckendorf, T. Toratti, I. Smith, and T. Tannert, "Vibration serviceability performance of timber floors," European Journal of Wood and Wood Products, vol. 74, no. 3, pp. 353-367, 2016.

[20] H. B. Zhou, Studies on design methods for sound insulation of wood structure walls and vibration performance of wood structure floors, Ph.D. thesis, Chinese Academy of Forestry, Beijing, China, 2006.

[21] B. Zhang, B. Rasmussen, A. Jorissen, and A. Harte, "Comparison of vibrational comfort assessment criteria for design of timber floors among the European countries," Engineering Structures, vol. 52, pp. 592-607, 2013.

[22] S. G. Zhang and N. Yang, "Comparison of loading methods for single-person walking load in floor human-induced vibration," Journal of Beijing Jiaotong University, vol. 37, no. 1, pp. 152-156, 2013.

[23] W. B. Wang, Research on transfer function prediction method of metro environmental vibration response based on pulse experiment, Ph.D. thesis, Beijing Jiaotong University, Beijing, China, 2011.

[24] Ministry of Housing and Urban-Rural Development of the People's Republic of China (MOHURD), JGJ/T 265-2012. Technical Code for Light Wood Trusses, Ministry of Housing and Urban-Rural Development of the People's Republic of China, Beijing, China, 2012.

[25] D. Casagrande, I. Giongo, F. Pederzolli, A. Franciosi, and M. Piazza, "Analytical, numerical and experimental assessment of vibration performance in timber floors," Engineering Structures, vol. 168, pp. 748-758, 2018.

[26] I. Smith and Y. H. Chui, "Construction methods for minimizing vibration levels in floors with lumber joists," Canadian Journal of Civil Engineering, vol. 19, no. 5, pp. 833-841, 1992.

[27] B. Zhang, A. Kermani, and T. Fillingham, "Vibrational performance of timber floors constructed with metal web joists," Engineering Structures, vol. 56, pp. 1321-1334, 2013. 